\title{
ONOMASTIC MATERIAL IN THE DESCRIPTION OF THE CAUCASUS BY JÓZEF CHODŹKO - A NINETEENTH-CENTURY POLISH SCHOLAR AND SURVEYOR
}

Keywords: Józef Chodźko, the Caucasus, geographic names in Chodźko’s manuscript

In the collections of the Library of Arts and Sciences at the Polish Academy of Arts and Sciences and the Polish Academy of Applied Sciences in Kraków (Poland) one can find a unique manuscript entitled "Orografia Kaukazu Józefa Chodźki" [The orography of the Caucasus by Józef Chodźko] written in 1864 (Furier, 2001, p. 129). ${ }^{1}$ This is the first Polish description of the Caucasus.

The aim of this paper is to call attention to the multidimensional value of the handwritten work of Józef Chodźko. This actually unknown manuscript of Polish investigator of the Caucasus includes not only valuable descriptions of the geography of the Caucasus but also very valuable onomastic material which may be interesting for linguists working on geographic names of the trans-Caucasian and the Caucasian regions.

The author of the manuscript, Józef Chodźko, was an experienced Polish surveyor and geographer. ${ }^{2} \mathrm{He}$ was born on 19 December 1800 into a Polish patriotic family on their family estate of Krzywicze in the Vilnius region. In 1821, he completed his studies in mathematics and physics at Vilnius University, also attending some courses in astronomy and land-surveying. In 1820 the Tsarist authorities

\footnotetext{
${ }^{1}$ For the purposes of the present publication, both the original manuscript (in a microfilm form) and Furier's book were used.

${ }^{2}$ Chodźko's biographical data concerning his life and activity are drawn from the Polish Biographical Dictionary (PSB, 1937, vol. III, pp. 385-386) and Furier's publications.
} 
decided to conduct surveying in the whole area of Russia. The basis for the surveying was triangulation - a method which measures the distance between the particular points of the measured area. Thus, the above-mentioned measurements enabled the preparation of accurate maps of the areas covered by surveying. The geodesic works also comprised the Vilnius province, which after the third partition of Poland (1795) was occupied by Russia. The Tsarist authorities commissioned the task of conducting surveys of this area to Józef Chodźko's University lecturer - Colonel Karl Tenner. A young graduate of the Vilnius University, Józef Chodźko also became a part of Tenner's group with the consent of the university authorities. This moment of his life was not only the beginning of his professional career as a surveyor and cartographer but also constituted a starting point in his compulsory military service in the Russian army because the Tsarist authorities only commissioned these kinds of tasks to military service men. The talented Chodźko was sent to a southern region of Russia in 1831 and from there to Moldavia and Walachia, where he was entrusted with the task of working out by himself the map of that region. At the same time, he obtained promotion to the rank of captain.

A subsequent stage in the career of the Polish surveyor was his assignment to service in an infantry division quartered in the Balkans, where Chodźko was to prepare topographic maps of a Danubian fortress - Silistria. In 1840 he was transferred to the Caucasus which after the Russian-Persian war in 1827-28 was already occupied by Russia in a region on the coast of the Black Sea. It is appropriate to add that the common practice of Russian authorities at that time was also to commission the preparation of maps of new territories where control had been assumed by Russia. The Russian war for the Caucasus continued until 1864, although the triangulations of the trans-Caucasian region began, according to the official information, in 1842, with Józef Chodźko as the one who was charged with the task of its supervision. The triangulation work of that region took Chodźko 24 years to complete, which according to his own words, was the best period of his life.

It is worth mentioning that one of Chodźko's greater achievements, albeit one that was not geodesic but Alpinistic in nature, was his ascent of Great Ararat which took place on August $18^{\text {th }}$ in 1850. Józef delivered an account of that achievement to his brother, the Orientalist Aleksander Chodźko, who lived in Paris at that time. Thanks to it, some articles about Chodźko's achievement were published in French and Russian journals and newspapers. At that time Chodźko was promoted to the rank of colonel and, in 1852, to the rank of major-general. One should also mention Chodźko's astronomical interests, testimony of which is furnished by his observation of a complete solar eclipse which took place on July 16/28 1851. His description of this phenomenon was published in Tiflis in 1852 in a publication of the Russian Imperial Geographic Society entitled "Svod nablûdenij proizvedennyh $\mathrm{v}$ raznyh mestah kavkazskogo i zakavkazskogo kraja 
nad solnečnym zatmeniem byvšym 16/28 iûlâ 1851 goda..." [The collection of remarks from various places of the Caucasian and trans-Caucasian region on a solar eclipse made on 16 to 28 of July $1851 \ldots$... The manuscript of this work is available also in the Archive of the Polish Academy of Arts and Sciences in Kraków, under the catalogue number of 202794 III.

In a discussion of his membership of the Russian Imperial Geographic Society, one should say that Chodźko was one of the co-founders and a very active member of the said society, which began its activity in 1851 . The Crimean war (1853) interrupted the triangulation-related work only temporarily, thus soon after Chodźko continued his task. His publication about his previous survey in the trans-Caucasian region to the Black Sea was published with a supplement about the work on the area around Ararat in Saint Petersburg in 1858. In 1862 the talented cartographer was again promoted, this time to the rank of lieutenant-general and decorated with the order of the White Eagle. He retired in 1867 (Furier, 2001, p. 88). This new-found state of repose enabled the Polish researcher to pursue a number of private plans, to renew contacts with his family scattered around the world and also to tighten the bonds of scientific relations. At that time, Chodźko traveled widely, especially to Germany and France. During his journeys he also visited Kraków, where he met Józef Majer, the chairman of the Polish Academy of Arts and Sciences, which was established in 1871 after the transformation from the Kraków Scientific Society. Józef Chodźko passed away in Tiflis on March 5 1881 (Furier, 2001, p. 125).

As already mentioned, the work on the triangulation of the Caucasus, the major part of which was personally carried out Chodźko, took him a dozen or so years.

The descriptions of the Caucasus and the results of the survey are in the form of a manuscript work (59 pages) and were originally written in French in 1864, as Józef Chodźko's intention was to publish the results of his work in France. His aforementioned brother, Alexander, lived in Paris and attempted to get Józef's work published there, unfortunately without success. Later on, the manuscript was probably delivered to the library in Rapersville, where it vanished (Furier, 2001, p. 9). The Polish translation of the original French version entitled "Orografia Kaukazu Józefa Chodźki..." [Orography of the Caucasus by Józef Chodźko] was prepared by Chodźko's friend - Ludwik Młokosiewicz. Fortunately, the only Polish manuscript version survived and is still available.

As for the Russian version of Chodźko's work, one can state that some parts of his reports from different stages of the triangulation of the Caucasus, presumably written in Russian, were previously published in Russian periodicals. In the 1880s Chodźko worked on summarizing his surveying and research carried out in the Caucasus which resulted in a posthumous publication in 1884 written in Russian and entitled: "Obščyj wzglâd na orografiû Kavkaza" [General remarks on the orography of the Caucasus] (Furier, 2001, p. 122). 
Written in 1864 the "Orography of the Caucasus by Józef Chodźko" consists of two parts. The first part, ${ }^{3}$ which bears the title "Rzut oka na trygonometryczne wymiary Kaukazu od 1847 roku do jesieni 1863 roku" [Trigonometric Measures of the Caucasus from 1847 to Autumn 1863 at a Glance] presents the process of the triangulation of the Caucasus. It also includes some information about Chodźko's journey to the Caucasus Mountains. We may infer from the author's own words that he began his work in 1840, conducting the first survey near the mountain Kodżory [Kojori] ${ }^{4}$ which is several kilometers west of Tiflis (i.e. former name of Tbilisi). In this part of the work, the author presents the method of the surveying and meteorological conditions of the measured region. He also provides information about the people involved in the process of surveying, mentioning their names and military ranks. Presenting the names of particular places where the survey was carried out, Chodźko also provides information about the type of terrain, the local nature, and geological formations. He even does not forget to mention meteorological difficulties and some health problems related to the members of the team who conducted the survey. Among other things, he mentions the cholera epidemic which was prevalent in the southern Caucasus in 1847 in the area where the survey was carried out. As a result of this disease, several members of the triangulation team died; Chodźko mentions their names in the work in question. Geographical names that appear in this part of the manuscript, such as: oronyms, toponyms, hydronyms are in most cases woven into a geodesic report informing about the particular work on a particular area. It is also appropriate to add that when he presents the particular distances between the measured points, Chodźko uses verst (in Polish: wiorsta ${ }^{5}$ and sażeñ ${ }^{6}$ ) as measures of length. When he provides the altitude of mountains, the author uses the English foot (equal to 12 inches) as a unit of length which was commonly used in the $19^{\text {th }}$ century and sometimes also the Russian foot. Sometimes, however, the author gives the altitude in sażeń converting it to the English foot.

The second part of the manuscript, ${ }^{7}$ entitled "Rzut oka na orografię Kaukazu" [The Orography of the Caucasus at a Glance] constitutes a geographic description of the Caucasus. Despite the fact that the author declares that his geographic description concerns only the Russian part of the Caucasus, in fact, the Caucasian areas that were administered by Turkey and Persia are also presented here.

\footnotetext{
${ }^{3}$ In the manuscript, this part includes pages from 1 to 18 .

${ }^{4}$ The geographic names quoted from Chodźko's work are presented here in the author's spelling, however some of them are additionally written according English spelling, what is appended in square brackets.

${ }^{5}$ A former Russian unit of length $=500$ sążeń $=1.0668 \mathrm{~km}$ (Nowa encyklopedia powszechna PWN, t. 6, p. 799).

${ }^{6}$ A former Russian unit of length, 1 sążeń $=2.1336 \mathrm{~m}$ (Furier, 2001, p. 145).

${ }^{7}$ This part includes pages from 19 to 27 .
} 
At the beginning of this part of his work, Chodźko focuses on the description of the mountain massifs of the Caucasus. He also refers to reminiscences and descriptions of other explorers of the Caucasus - those of a Russian general, Dominik Milutin, and of a German scholar, Herman Abich. After the first general descriptions of the Caucasus, where he also emphasizes how difficult it was to make an accurate division of mountain massifs, in accordance with the rules, the author introduces the division of his description into three regions: the great Elbrus valley; the great Dagestan valley; the Caucasian part of the Great Ararat valley.

In each part he presents the division into smaller valleys, mentioning the rivers which flowed there, some places in that region and also mountain peaks.

He describes the great Elbrus valley as the area where in its central part there is the Elbrus chain $270 \mathrm{~km}$ in length with two summits — Osztek [Oshtek] in the west and Szan [Shan] in the east. This enormous valley consists of smaller ones: where in the north there are six, in the south - eight. Altogether, there are 14 smaller valleys, which are formed by various rivers running there, among others: Rion, Aragwa [Aragva] Kura, Matka [Malka], Baksan, Terek, Sunża [Sunzha], Assa. In the area of the great Elbrus valley the author names the following mountain peaks: Dich-tau [Dikh-tau] (16,946 English feet), Adaj-hoch [Aday-hokh] $(15,244$ feet), Tepli (14,500 feet), Kazbek (16,456 feet). In reference to the region that was mentioned the author alludes to the town of Stavropol, a small settlement known as Tioneti [T'oneti] and also a ravine, Manitcza [Manitcha].

The second large valley presented in this part is the great Dagestan Valley. The author considers the Szunu dach [Shunu dakh] mountain in southern Dagestan (9,133 feet) to be the central point of this valley. Just as in the description of the great Elbrus Valley, also in this case the author remarks that the great Dagestan Valley is made up of three smaller valleys south of the central range and of eight valleys in the north. Chodźko states that the mountain peaks in the central range of this valley are not lower than 8-9 thousand feet. The subsequent part of his description refers to the Caucasian part of the Great Ararat Valley.

The description begins with the statement that the southern Caucasus, from the right bank of the Kura River up to the border with Turkey and Persia, consists of 13 small valleys where Great Ararat $(16,916 \mathrm{ft})$ soars at the center. The presentation of this valley starts with an enumeration of the highest peaks of the Caucasus from east to west. These are the following: Alagiez [Alag'ez], Ararat, Elbrus, Kapudzich [Kapujikh], Kazbek, Kesa-dach [Kesa-dakh], Kirs, Osztek [Oshtek], Ostryj [Ostriy] (near Stavropol), Sawelan [Savelan], Szach-dach [Shakh-dakh], Szan [Shan], Szerdari [Sherdari] (in Persia), Surpchacz [Surpkhach]. Next, below the description the author presents the list of the previously mentioned peaks in a special table together with their altitude and co-ordinates.

In further remarks included in this part of the manuscript (part II) one can find an in-depth description of thirteen smaller valleys constituting the Caucasian part 
of the Great Ararat Valley. The author enumerates mountain ranges that form this particular small valley, their peaks with their altitude and the rivers which flow there. Chodźko admits that the Caucasian part of the Great Ararat Valley is much larger than the valleys of Elbrus and Dagestan. The Caucasian part of the Great Ararat Valley takes up 200,000 square versts (800 in length and 250 in width), whereas the Elbrus Valley takes up only 40,500 square versts (270 in width, 150 in length) and the Dagestan Valley is 74,000 square versts (370 in length and 200 in width). In the final remarks in this part of the manuscript the author emphasizes that in his description he focused exclusively on the orography of the Caucasus, in the hope that this very subject would attract the attention of specialists and researchers. He also adds that in his work he purposely did not describe the elements of nature, such as rivers, lakes, forests or steppes, leaving this subject for other specialists to explore.

After the second part of the manuscript there is a supplement which ends with the page marked by the number 59. In fact, this alleged supplement constitutes the third part of the manuscript, in a form of a list of 1,002 measured points situated in the Caucasus, the trans-Caucasian area and in Turkey and Persia. In contradistinction to part one and two of the presented manuscript this part was already published in 1856 in Tiflis. That is why the author gives to this part of the text the following name: "Tablica wysokości nad powierzchnią morza 1002 punktów Kaukazkiego i Zakaukazkiego kraju, w Turcji i Persyi oznaczonych za pomocą barometru i gieodezji itp. środków, tłomaczone z Kaukazkiego kalendarza 1856 roku - wydanego w Tyflisie z dozwolenia Iego Cesarskiej Mości za staraniem Namiestnika Kaukazkiego Xola Woroncowa" [The table of 1,002 points above the sea level on the Caucasus, trans-Caucasian region and in Turkey and Persia measured with the use of barometers and geodesic instruments, translated from the Caucasian calendar 1856, published in Tiflis with the permission of His Imperial Majesty and thanks to the efforts of the Caucasian governor - Khola Vorontsov].

This part of the text is divided into 48 subchapters and a short appendix. The criteria of the division of the material which is included are not only geographical. In the separate subgroups, the author presented the list of measured points such as mountains, various places, river banks, water reservoirs and also points marking out the boundaries of forests, vineyards, barley and wheat fields, the growth of grass, etc. In the final appendix, the author presented 20 points situated in the Asiatic part of Turkey and in Persia.

As far as linguistic research is concerned, and especially onomastics, it is this part of Chodźko's work that seems to be the most interesting. In this part of the manuscript the author collected all names of measured points which appear in previous parts. These names are presented in a form of a table together with data concerning the altitude and the performer of survey. 
The bulk of the onomastic material collected in this table constitutes oronyms, then hydronyms, micro-toponyms. This quite abundant onomastic material included in Chodźko's work constitutes a very valuable historical source for various linguistic studies.

The onomastic material gathered in Chodźko's work, is doubtlessly of great worth for linguistic research in such areas as: the history of geographic names and their etymology. For scholars working on Turkic, Indo-European or Caucasian languages the present manuscript constitutes a rich source of material. For the sake of presenting some examples, the following list provides some names excerpted from Chodźko's work which seem Turkic as far as their origin is concerned:

1. Alagiez [Alag'ez] (mountain), Yerevan district, altitude 13,346 ft.; cf. Az., Tur. < Ar. allah 'God, Allah', göz 'eye'8. Chodźko explains the meaning of this oronym as "Oko Boże" [God's Eye] (Furier, 2001, p. 141). Thus, according to Chodźko's conception, the oronym is motivated by two nouns written together in the form Ałagiez. Therefore, the first segment (Ała-) presumably comes from a proper noun, Allah, in its misshapen form, whereas the second segment giez 'eye' represents a common noun.

2. Arpa giol [Arpa g'ol] (lake), Asiatic Turkey, altitude, 6,400 ft; cf. Az., Tur., Kum. arpa 'barley', Az., Turk. göl 'lake', Kum. köl, kol 'lake'. The hydronym Arpa giol meaning 'barley lake' is motivated by two common nouns denoting elements of nature.

3. Baba-dah (mountain), Shamakha province, altitude 11,900 ft; cf. Az. baba 'grandfather', Tur. baba 'father, elderly man', Az., Tur. da g 'mountain', Kum. tav 'mountain'. This oronym meaning 'father's mountain' is formed by two common nouns where the first one $b a b a$, widespread among Turkic languages, has many denotations semantically connected with family relations. The first element qualifies the second element dah meaning 'mountain'.

4. Besztau [Beshtau] (mountain), altitude 4,585 ft; cf. Az., Tur. beş 'five', Kum. beš 'five', Az., Tur. dăg 'mountain', Kum. tav 'mountain'. In the oronym Besztau meaning 'five mountains' one can recognize two Turkic words, i.e.: the numeral besz 'five' and a Turkic common noun tau 'mountain' which in various Turkic languages appears in different variants - dah, da $\breve{g}$, tau, tav and others.

5. Bori su (mountain), altitude 2,037 ft; cf. Az., Tur. boru 'pipe, tube', Kum. bïgï 'trumpet, horn', Az., Tur. su 'water', Kum. suv 'water'. The name of the mountain peak Bori su 'pipe water' is motivated by two common nouns. One cannot exclude that semantic motivation for this name can relate to the shape of the mountain.

${ }^{8}$ The original spelling of the geographical names collected here is, in most cases, confronted with the Azerbaijani, Turkish and Kumyk words to show their similarity. 
6. Indża-su [Inja-su] (mountain), Aleksandropol district, altitude 9,790 ft; cf. Az. incə thin, delicate', Tur. ince 'delicate, thin', Kum. dial. inčkä 'delicate, thin', Az., Tur. su 'water, fluid; also: brook, stream', Kum. suv 'water, stream'. The name Indza-su 'thin, delicate brook, stream' comprises two words, i.e.: an adjective indża 'thin, narrow' and a common noun su 'water'. Presumably the name of the mountain relates to the river which takes its source there.

7. Kapudżych [Kapujikh] (mountain), Ordubat district, altitude 12,860 ft; cf. Az. qapı 'door', Kum. qapu, Ott. Tur. kapu 'gate, door', modern Tur. kapı 'door, gate', kapıcık 'dimin. of kapl'. Presumably, the motivation for this oronym can be related to the shape of the mountain.

8. Kara kaja [Kara kaya] (mountain), near Borżom [Borzhom], altitude 9,360 ft; cf. Az. qara 'black', Tur., Kum. kara 'black', Az. qaya 'rock', Tur., Kum. dial. kaya 'rock'. The name of the mountain Kara kaja 'black rock' is motivated by a common noun kaja 'rock' which is qualified by an adjective kara 'black'.

9. Karatych-dah [Karalikh-dah] (mountain), Darałagiez [Daralag'ez] district, altitude 11,120 ft; cf. Az. qaranlıq 'dark, darkness', Tur. karalık or karanllk 'darkness', Az., Tur. da g 'mountain', Kum. tav 'mountain'. The name of the mountain (dah) is motivated by its colour (karatych).

10. Kior-ogty [K'or-ogly] (mountain), altitude 6,682 ft; cf. Az. kor 'blind', Tur. kör 'blind', Az. Tur. oğul 'son', also Tur. Köroğlu 'hero of a popular legend and traditions'. This name is formed by two elements, i.e.: the substantivized adjective kior meaning 'blind man' and the noun ogty (ogul + poss. suf. of third per.) 'his son'. Therefore, this geographic name means 'a son of a blind man'. However, one can also conceive that this oronym is motivated by a proper noun denoting a legendary individual - Köroğlu.

11. Kula tasz [Kula tash] (mountain), Ararat valley, altitude 7,278 ft; cf. Az. dial. gula 'light yellow', Tur. kula 'russet', Kum. kula 'brown', Az. daş 'stone', Tur. taş 'stone', Kum. taš 'stone'. The oronym Kula tasz meaning 'russet stone' is motivated by the adjective denominating the colour ( $k u l a$ ) and the noun tasz 'stone'.

12. Kyrch-kiz [Kirkh-kiz] (mountain), Karabakh district, altitude 9,350 ft; cf. Az. qurx 'forty', Tur. kırk 'forty', Az. qlz 'girl, maiden', Tur. klz 'girl, maiden'. From grammatical point of view the name Kyrch-kiz 'forty maidens' is formed by two elements where the numeral kyrch 'forty' qualifies the noun kiz 'girl, maiden'.

13. Tasz-burun [Tash-burun] (mountain), Karabakh district, altitude $470 \mathrm{ft}$; cf. Az. daş 'stone', Tur. taş 'stone', Kum. taš 'stone', Az., Tur., Kum. burun 'nose; also: cap, point'. The name Tasz-burun 'stony nose' relating to the nose-like shape of the mountain is motivated by two common nouns tasz 'nose' and burun 'nose'.

The above-mentioned toponyms of Turkic origin represent two groups of geographic names, namely oronyms and hydronyms. As for the latter, there is only one, single example of hydronym, i. e. Arpa giol. It is proper to add that among quoted oronyms there are two names (Indża su, Bori su) which in accordance with 
their meaning should be categorized as hydronyms however they both denote mountain peaks.

An onomastic analysis of the presented material indicates that most of the geographic names are motivated by lexemes denoting elements of nature, such as: water, mountain, rocks, plants which are qualified by adjectives denoting colors, numerals or physical features.

Also, some oronyms have motivations related to their shape (Tasz-burun, Kapudzych, Bori su). There are also three oronyms that presumably relate to historic, religious or legendary ideas or individuals (Alagiez, Kior-ogly, Kyrch-kiz).

As far as the spelling of the onomastic material is concerned, as one can see, the vocabulary included in Chodźko's work is written in a Polonized form. Therefore, one cannot exclude misspelled and distorted onomastic forms which can be found in the manuscript.

On page 52 of the manuscript one can find a remark most likely written by the translator who was, as it was mentioned before, Chodźko's friend — Ludwik Młokosiewicz. The translator expresses some doubts concerning the appropriate translation into Polish and the problems of the spelling of particular geographical names (Furier, 2001, p. 132).

In a presentation of Chodźko's work it is also appropriate to mention its ethnographic and historical value. In the part which we mentioned, the supplement, the author provided not only geographical proper names but also common names designating some objects which were situated in the surveyed area, e.g. in the subchapter number $\mathrm{X}$ which presents the measured points from Tiflis and its vicinity the author mentions an astronomical observatory located at the level of 1,510 ft, an Orthodox Church dedicated to John the Baptist at the altitude $1,390 \mathrm{ft}$, and also a bridge on the Kura River at the altitude of $1,350 \mathrm{ft}$. This sort of data, together with accurate co-ordinates of those items are of great utility in the reconstruction of the fine points of local topography and the history of local places and points.

Furthermore, one cannot forget that it was thanks to Chodźko's ideas and strategy that he applied in surveying that the drawing of the first exact maps of the Caucasus became possible.

In conclusion, one should ascertain that Józef Chodźko's work constitutes an important source for research in various scientific areas, namely: in geography, ethnography, geodesy, cartography and last, but not least, in onomastics. As for onomastics, we should be aware that it will be impossible to explain the semantic motivation of some geographic names from the Caucasus without the thorough study of the local culture, geography and history of the region.

Last but not least, Chodźko's biography needs appropriate treatment, since for many years Russian and Soviet scholars tried to diminish his merits, or even claimed that he was not a Polish surveyor but a Russian one. 


\section{REFERENCES}

Azarbaycan-Ingilis. Ingilis-Azarbaycanca lüğət [Azerbaijan-English. English-Azerbaijani Dictionary]. (2003). Bak1: Bakı Universiteti Nəşriyyatı.

Blagova, G.F. (Ed.). (2000). Ètimologičeskij slovar'tûrkskih âzykov [Etymological Dictionary of Turkic Languages]. Moskva: Izdatel'stvo Indrik.

Chodźko, J. (n.d.). Orografija Kaukazu Józefa Chodźki [The Orography of the Caucasus by Józef Chodźko] z francuskiego przez L.M., tudzież Pomiary wysokości gór wyciag z Kalendarza na r. 1856. Manuscript. Biblioteka Naukowa Polskiej Akademii Umiejętności i Polskiej Akademii Nauk, Kraków, sygn. 1252.

Chodźko, J. (n.d.). Svod nablûdenij proizvedennyh v raznyh mestach kavkazskogo i zakavkazskogo kraja nad solnečnym zatmeniem 16/28 iûlâ 1851 goda [The Collection of Remarks from Various Places of the Caucasus and Trans-Caucasian Region on a Solar Eclipse Made on 16 to 18 of July 1851]. Manuscript. Biblioteka Naukowa PAU i PAN, Kraków, sygn. 202794 III.

Dybo, A.V. (Ed.). (2003). Ėtimologičeskij slovar'tûrkskih âzykov [Etymological Dictionary of Turkic Languages]. Moskva: Vostočnaâ literatura RAN.

Đliyev, V. (1999). Azarbaycan toponimiyası [Toponymy of Azerbaijan]. Bakı: Nurlan

Furier, A. (1998). Józef Chodźko — mierniczy Kaukazu [Józef Chodźko — Surveyor of the Caucasus]. Przegląd Wschodni, 4(4), 819-851.

Furier, A. (2001). Józef Chodźko 1800-1881. Polski badacz Kaukazu [Józef Chodźko 1800-1881. Polish Explorer of the Caucasus]. Warszawa: Trio.

Gałkowski, A. (2012). Terminologia onomastyczna [Onomastic Terminology]. https://onomastyka.uni.lodz.pl/strona-glowna/terminologia-polska

Gejbullajev, G.A. (1986). Toponimiâ Azerbajdžana. Istoriko-ètnografičeskoe issledovanie [Toponymy of Azerbaijan. Historical-Etnographic Study]. Baku: Èlm.

Languages of the Caucasus (2020, May $1^{\text {st }}$ ). https://en.wikipedia.org/w/index.php?title=Languages of_the_Caucasus\&oldid $=954251758$

Lewis, G.L. (1975). Turkish Grammar. Oxford: Oxford University Press.

Məmmədov, N.Q. (1993). Azərbaycanin yer adları [Azerbaijani Toponyms]. Bakı: Azərnəşr.

Nowa encyklopedia powszechna [New Universal Encyclopedia] (1997). Warszawa: PWN.

PSB = Konopczyński, W. et al. (Ed.). (1937). Polski stownik biograficzny [Polish Biographical Dictionary] (Vol. 3). Kraków: PAU.

Məmmeədli, A.M. (Ed.). (2005). "Qafqaz dillar va madaniyyatlar”. Elmi camiyyatinin asarlari. Trudy naučnogo ob̌̌čestva "Kavkaz. Jazyki i kultury”. Proceedings of the scientific association "The Caucasus. Languages and cultures». Bak1 Slavyan Universiteti. Bak1.

Räsänen, M. (1969). Versuch eines etymologischen Wörterbuchs der Türksprachen. Helsinki: Suomalais-Ugrilainen Seura.

Redhouse Yeni Türkçe-Ingilizce Sözlük [New Redhouse Turkish-English Dictionary] (1981). Istanbul: Redhouse Yayınevi.

Reychman, J. (1972). Podróżnicy polscy na Bliskim Wschodzie w XIX w. [Polish Travelers to the Middle East in the $19^{\text {th }}$ Century]. Warszawa: Wiedza Powszechna.

Safiyeva, F. (2014). Materiaty dydaktyczne do nauki języka azerbejdżańskiego [Teaching Materials for Learning the Azerbaijani Language]. Warszawa: Oficyna Olszynka.

Sevortân, È.V. (Ed.). (1974). Ėtimologičeskij slovar 'tûrkskih âzykov [Etymological Dictionary of Turkic Languages]. Moskva: Nauka.

Sevortân, È.V. (Ed.). (1978). Ėtimologičeskij slovar'tûrkskih âzykov [Etymological Dictionary of Turkic Languages]. Moskva: Nauka.

Sevortân, È.V. (Ed.). (1980). Ėtimologičeskij slovar' tûrkskih âzykov [Etymological Dictionary of Turkic Languages]. Moskva: Nauka. 


\author{
SUMMARY \\ ONOMASTIC MATERIAL IN THE DESCRIPTION OF THE CAUCASUS BY JÓZEF CHODŹKO - \\ A NINETEENTH-CENTURY POLISH SCHOLAR AND SURVEYOR
}

Józef Chodźko (1800-1881) was one of the first explorers of the Caucasus and an experienced Polish surveyor and cartographer who surveyed the trans-Caucasian and the Caucasian regions. Thanks to the method of triangulation, he made precise measurements of that region which subsequently enabled the preparation of the maps of the Caucasus. During his survey in the Caucasus region, Chodźko prepared a description of the places surveyed in manuscript form entitled "Orografia Kaukazu Józefa Chodźki”.

The aim of this paper is to call attention to the multidimensional value of this handwritten work. This previously unknown manuscript by the Polish investigator of the Caucasus not only includes valuable descriptions of the geography of the Caucasus but also very valuable onomastic material which may be interesting for linguists working on the geographic names of the trans-Caucasian and the Caucasian regions. His work includes many geographic names: oronyms, hydronyms, macroand micro-toponyms and other names of objects the author described in his work. In respect of the etymology the onomastic material recorded by Chodźko represents various linguistic families, such as: Altaic, Indo-European, Caucasian. In the present paper, as an example, some geographic names which seem to be Turkic are shown. The onomastic material included in Chodźko's work constitutes a valuable source for research on the history and etymology of geographic proper names from the region of the Caucasus. Therefore, linguists, especially those who are engaged in onomastic studies, should take a keen interest in Chodźko's "Orografia Kaukazu”. 